\title{
BIRDS, FROGS AND TINTERN ABBEY: HUMANISM AND HUBRIS
}

\author{
MICHAEL MCGHEE
}

University of Liverpool

\begin{abstract}
David E. Cooper proposes that the 'mystery' of 'reality as it "anyway" is, independently of human perspective' provides measure for the leading of our lives and thus avoids, on the one hand, the hubris of a humanism for which moral life is the product of the human will and has no warrant beyond it, and, on the other, a theism which appears to be at once too remote from and too close to the human world to provide any such warrant. The paper rejects the role this gives to 'mystery' and locates 'warrant' in a moral perspective that is not the product of will.
\end{abstract}

Over fifty years ago an Indian philosopher, Daya Krishna, attended a symposium in the West on the philosophy of religion. In an insightful paper he reflected on his experience, and mildly remarked how skewed the discussions were by an unselfconscious concentration on Christianity. He was drawing attention to a bias that has hardly changed since:

The other great limitation of the discussion ... was its confinement, perhaps naturally, to Christianity alone. It was as if one were to reflect on aesthetic experience and confine one's discussion to Greek art or the Renaissance masters only ... That no one challenged this implicit limitation shows once again the difficulty of getting beyond the perspective of the culture one happens to be born in. ${ }^{1}$

${ }^{1}$ Daya Krishna, 'Religious Experience, Language and Truth', in Religious Experience and Truth, ed. by Sidney Hook, (New York: New York University Press, 1961) and reprinted in The Art of the Conceptual: Explorations in a Conceptual Maze Over Three Decades (Delhi: Indian Council of Philosophical Research, 1989), pp. 112-121 (p. 114). 
Professional philosophers of religion were mainly Christians and exChristians and their main work would have been on the efficacy of the proofs for the existence of God and of the rationality of belief as these questions were received through the European traditions. They would mostly acknowledge, if nudged, their debt to the Jewish and Arab philosophers, but would return to focus on the current state of the argument as represented by their contemporaries. The Eastern traditions were largely ignored, by philosophers of religion, but also by western philosophers generally, who would fail to see much 'philosophy' there at all.

That these traditions are now slightly less ignored, at least by younger members of the profession, is thanks to such thinkers as David Cooper, whose work has helped us expand our notion of what it is to do philosophy at all. Cooper is one of the very few philosophers in the United Kingdom to have broken free from this cultural limitation and indeed from the more inward-looking, self-referential forms of analytic philosophy, looking first towards forms of continental philosophy which try to answer questions that analytic philosophy has not thought to ask. ${ }^{2}$ But the gradual shift of perspective that opens to view the influence of the Asian and East Asian traditions on the Western, in the work of Schopenhauer, Nietzsche and Heidegger - and in the latter case the influence was crucially mutual - owes much to Cooper's developing sense of World Philosophy, a sense that helps us redefine the philosophical canon. There is a political dimension to this. Nowadays certain politicians and Churchmen, catching an unpleasant public mood, express anxiety about 'multiculturalism', which they conceive as a restive, mutually incurious and tensely maintained tolerance between communities politically correct but refusing to engage - whereas the possibilities for fusion, artistic, intellectual and spiritual, are now starting to become available. We sometimes wring our hands about the public engagement of philosophers, but Cooper's work, first of all on continental philosophy and later on world philosophy, particularly the Eastern traditions, has shown how a critical cultural engagement is possible - an engagement which some might think alters our conception of what the philosophical questions are.

\footnotetext{
${ }^{2} \mathrm{~A}$ point made in conversation by Michael Weston (University of Essex).
} 


\section{COMMON GROUND AND SCEPTICISM ABOUT 'MYSTERY'}

David Cooper's writing is analytically sharp, but also sometimes indirect and elusive in ways which are creatively engaging. In what follows I shall express some scepticism about his direction of thought in a recent paper, 'Mystery, World and Religion,' ${ }^{3}$ but the scepticism derives from a perplexity which I hope makes for a fruitful conversation and it may be that I have failed to understand him and am at cross purposes.

Cooper seeks to contend against what he calls 'a raw, hubristic humanism, ${ }^{4}$ but also to avoid what a surprising number of thinkers take to be the only alternative, some version of theism, ${ }^{5}$ thinkers who take humanism to be essentially hubristic, on the grounds that it depends upon the disposition of the human will. This puts Cooper in a very interesting position because it looks as though, inspired by East Asian traditions, he is seeking middle ground between the great polar opposites of contemporary religious debate, a middle ground as it might seem between secularism and theism - though more plausibly between secularism and 'religion', since it is hard to see how there can be middle ground between what are presumably exclusive alternatives. On the other hand, however, there can be common ground between the protagonists and this may be the middle ground between secularism and religion if we can see some aspect of the religious life, some aspect of what we might still want to call spirituality, that allows us to make sense of that idea. One of the salient features of Christianity is the terror and hope of the Garden of Gethsemane, the crucifixion, and the resurrection - and if we prefer a different symbolism because of anxiety about metaphysical commitments, that's fine so long as we don't neglect in our thinking the passages of life that we find need ritual re-enactment and expression. If our secularism is obsessed with an anti-theological triumphalism, it may neglect the necessary poetry - or the reflective reading of that poetry that together with it contributes to a cultural tradition which enshrines and depicts our profound predicaments and moral conflicts.

${ }^{3}$ David E. Cooper, 'Mystery, World and Religion', in Philosophers and God: At the Frontiers of Faith and Reason, ed. by John Cornwell and Michael McGhee (London: Continuum, 2009), pp. 51-62.

${ }^{4}$ An expression which leaves open the possibility that there can be an unraw and unhubristic humanism.

${ }^{5}$ See, for instance, Gordon Graham, 'Religion and Theology', Philosophers and God: At the Frontiers of Faith and Reason, ed. by John Cornwall and Michael McGhee (London: Continuum, 2009), pp. 217-230. 
Cooper seems to locate the middle ground when at the beginning of his paper he describes the path that led him to think that

(R)eality as it 'anyway' is, independently of human perspective, is mysterious. ${ }^{6}$

The question, of course, is whether this is true, though that question must wait upon an interpretation of the remark. Is it true that 'reality as it "anyway" is, independently of human perspective' is 'mysterious'? What is being claimed? It is the reference to mystery and the role Cooper wants to give it that I find perplexing. He construes 'mystery' as 'what cannot, even in principle, be conceptualised or literally articulated. But it does not seem to me that what cannot be conceptualised - what is not 'discursive', to use the word Cooper borrows from Kant - is therefore 'mysterious'. But the role Cooper gives to 'the mysterious' is that it provides 'measure for the leading of our lives, something for these to answer to.' My doubts about the application of the term 'mystery' will lead to questions about just what can provide a 'measure for the leading of our lives' ... 'something for these to answer to'. This in turn will lead to reflection on the question whether humanism is essentially 'hubristic' or whether particular formulations of it lead to that impression.

\section{INTIMATIONS OF ... 'THE MYSTERIOUS'?}

Even within common experience there is much that cannot be described or 'conceptualised' - except by comparison to other things that also cannot be described, as a wine taster identifies the aroma of strawberries or plums in the bouquet of a wine. Nor is there anything mysterious about the taste of a merlot, though it may be interesting. As for what goes beyond the possibility of human experience, ex hypothesi that cannot be conceptualised either - but is it to that extent 'mysterious'? The stakes are high, as we have seen - Cooper conceives its role as providing measure and something to answer to: something necessary but unavailable to a hubristic humanism.

It is important to see just how strange this claim is: it is 'reality' that is mysterious and thus provides the measure for the leading of our lives. Surely a very particular conception of reality is being invoked here and it is this which gives specific content to the notion of 'mystery' - but can

${ }^{6}$ David E. Cooper, 'Mystery, World and Religion', p. 51.

${ }^{7}$ David E. Cooper, 'Mystery, World and Religion', p. 55. 
any conception of 'reality' give content and point to talk of 'mystery' and what grounds do we have for supposing that what it supplies is a measure? Lots of things are 'mysterious' but under what conditions does that kind of talk become interesting?

But now, if 'the mysterious' is to play this role of providing a measure it is 'essential that one is offered intimations of, and an attunement to, the mysterious which enables the faith that lives led in certain ways do answer to, or are consonant with, the way of things.' ${ }^{8}$ This last expression, 'the way of things', is a revealing alternative to the bare talk of 'reality as it "anyway" is'. It is reminiscent of Taoist talk of the Way. It seems to me to at least make sense to talk of human conduct being attuned to or consonant with 'the way of things', or even to talk of 'the way of things' providing a measure, since it implies the idea of a rhythm of life that we can also fail to be attuned to and can come to see that this is so. But this attunement to or consonance with the way of things thus understood is not obviously a matter of being attuned to the mysterious - even if 'the way of things' eludes our conceptual grasp it does not follow that it is 'mysterious'.

Cooper talks of those who have come to a sense of 'the mystery of reality' through special experiences - what he calls 'Tintern Abbey moments'. But I wonder whether this is an example of a sense of 'the mystery of reality' or, rather, of a sense, well, to continue with Wordsworth, of 'something far more deeply interfused'. We often talk of a sense or intimation of 'something' that we cannot, at least at the moment, grasp or understand. But 'something far more deeply interfused' is a resonant phrase suggestive of the idea of an active presence coursing through all things, something, in other words, it is not difficult to think of as a divine, creative presence ... even if we conceive it in Spinozistic terms as natura naturans. It is a sense of that, though, of a presence within reality - or better, within the cosmos or 'creation' - rather than of 'mystery' or even of 'the mystery of reality'. As Wordsworth puts it, 'we see into the life of things', a phrase which suggests a kind of knowledge of 'the way of things', though not a conceptual knowledge, and it may indeed be as he says 'but a vain belief'. However, it may be that 'seeing into the life of things' transforms us in ways that we might call an attunement - not to mystery, indeed, but to the way of things.

Now once we start to reflect on what must be the nature of this presence and what we can know or understand of it, we might then

\footnotetext{
${ }^{8}$ Ibid., p. 62.
} 
start talking of 'mystery' - which is a word by which we acknowledge that such a nature is beyond our powers to discern or comprehend. It is what we cannot comprehend that makes the term 'mystery' interesting, and we shall come to that - but 'mystery' is not as it were the immediate object of what we sense or discern in the Tintern Abbey moment. What we sense is presence rather than mystery, even if we come to conclude that the 'presence' is indeed 'mysterious'. We might simply remain with The Prelude, with 'a dim and undetermined sense / Of unknown modes of being,' ${ }^{9}$ where the emphasis is on 'undetermined' but perhaps allowing us to move, through reflection, towards 'beyond human determination altogether' - but the object of this indeterminability is not 'reality as it anyway is' but simply 'unknown (or even unknowable) modes of being' - aspects and dimensions of reality that we are not aware of or cannot conceivably become aware of - though how this could provide a measure for living our lives is seriously problematic.

Talk of an active presence coursing through all things may be poetic but it is also philosophically incautious. Does the Tintern Abbey poem express a sense of the presence of the divine? Well, if it does, it would be a sense of divinity rather than of the 'mystery of reality' even if, as I have said, we conclude that the nature of that divinity must be a mystery to us. More to the point, though, these intimations are the work of the imagination leading to a surmise, a sense that there is a presence moving through all things. The phrase 'a sense of something' may imply a direct awareness or it may be used propositionally, a sense that there is something. That there is a propositional interpretation does not make the experience less profound. Wordsworth's 'blessed mood', in other words, does not put us in touch with 'the mysterious' but with what might lead us to think the idea of what must be mysterious in its ultimate nature. In the right sort of contemplative mood, the vivid and powerful forces of nature, whether serene or tempestuous, beautiful or sublime, can impress their presence upon us, and our sense of this presence works on the imagination and can give rise to or reinforce the idea of a divine creative reality of which these forces become the symbol or image. Not far from here they then step down in the form of Apollo or Athena or Poseidon ... whose 'reality' is constantly reaffirmed by the liveliness of the presence of the forces that symbolise them, putting us back in touch

${ }^{9}$ William Wordsworth, 'The Prelude' [1805], in The Complete Poetical Works of William Wordsworth, Henry Reed (ed.) (Philadelphia: Troutman and Hayes, 1852), p. 479. 
with what they themselves symbolise. There is sufficient epistemological humility available here without recourse to talk of mystery - in the thought that there are aspects or dimensions of reality, of what there is, that are beyond our grasp. But the Tintern Abbey moment gets us to 'mystery' only when we have already interpreted it theistically.

Cooper also refers to 'littler, humbler things ... like the frog-plopping, bird-cheeping and bamboo-rustling that have been the occasion for Zen poets to communicate their sense of the mystery of things. ${ }^{10}$ But is that what they seek to communicate, the 'sense of the mystery of things'? - as opposed, say, to their suchness, the suchness of these individual things, their haecceitas - 'it strikes like lightning to hear him sing. Cooper has talked of 'what cannot, even in principle, be conceptualised or literally articulated', but here we refer to what in experience cannot be conceptualised or articulated, viz. the resonant presence of particular things. The sound of the bird interrupts the flow of activities that generally prevent us from just listening - where 'just listening' is a dwelling in the experience rather than simply noting that a bird is singing. I imagine that the former would count as an example of 'non-conceptual experience', in the sense, perhaps, that its content is not accommodated within our concepts (its individuality is not what our concepts reveal), but it is also true that such experiences are not 'discursable' ... when we seek to communicate them, as with the Hopkins line, as with the wine or coffee, we do not so much describe them as compare them to other experiences that are equally non-discursable. The point here is that the sound of the bird does not give us a sense of the mystery of things - but we gain access to an aspect of reality that eludes the grasp of our concepts. The sound of the frog or that of the bird, the rustling of the bamboo, breaks a silence that is already an object of the Zen monk's attention as well as its condition. So it is also an image of reality manifesting itself to us within the limits of the senses, an image of what comes forth out of the silence when the mind is still, a perspective as well as an object.

\section{A THEOLOGICAL CIRCUMSCRIPTION OF 'MYSTERY'}

Although David Cooper is very well aware of the possible theistic moves here, moves from which, as we shall see, he has his own reasons to distance himself, it is nevertheless true, as I have just hinted, that

\footnotetext{
${ }^{10}$ David E. Cooper, 'Mystery, World and Religion', p. 51.
} 
talk of 'mystery' has traditionally had a specific theological content, though of course we use the term idiomatically to refer to something that we don't understand or that we lack information about, as when we can't work out whodunit. More fundamentally from the point of view of classical theism - which I seek here to present rather than defend - it is God's nature that is the ultimate and transcendent mystery, where the reference to mystery is very specifically to the nature of the source of all created things, a source which is beyond the order of all beings, supra ordinem omnium entium. It is this being beyond the order (or way) of things which gives content to the talk of mystery and the mysterious. We can, according to this tradition, know by the light of natural reason that there is a God; we can, moreover, know what God is not; what we cannot know is what God is. It is not reality but the divine nature that is mysterious, in the sense that the source and origin of all cannot but be beyond all comprehension, beyond understanding, not a possible object of experience. Even here we can make a distinction between the idea of what within the cosmos or the universe could not be conceptualised, and the divine source of that cosmos that is beyond comprehension. It is the latter that is 'mysterious'. What God is remains beyond all comprehension and is in this sense 'a mystery'. To put it another way, and to remain within this tradition, what accounts for the existence of things - 'what we call "God" as Aquinas phrases it - is beyond all human comprehension, and it is for this reason that it is called a mystery. What is 'mysterious' in this tradition is not 'reality as it "anyway" is' but the nature or being of what accounts for reality whether or not it is independent of human perspective.

If I may make a sideways move here, in relation to the proliferation of talk of mystery and 'the mysterious', it is significant that some philosophical theologians have wanted to say that the very existence of things is 'mysterious' - not that their nature is a mystery to us, but that they exist at all. This seems to me to be a mistake. It is the nature of what accounts for the very existence of things that is a mystery. What stands in need of accounting for is not 'mysterious'; it simply stands in need of accounting for. The 'mysterious' is precisely what cannot itself be accounted for. Herbert McCabe's seminal article, 'Creation, ${ }^{11}$ is I think responsible for a common misremembering of a famous sentence from Wittgenstein's Tractatus (6.44) in which he is quoted by McCabe as saying: 'it is not how things are in the world that is mysterious (sic), but

${ }^{11}$ Geoffrey Chapman, 'Creation', in God Matters (London: Continuum, 1987), pp. 2-9. 
that it is.' The phrase Wittgenstein uses in fact is das Mystische, a term he uses a little later in 6.45: 'Feeling the world as a limited whole - it is this that is mystical.'12 It is hard to see how 'mysterious' properly translates either remark, though the misquotation may reflect the direction of McCabe's thought as he reflects on the question, why is there anything at all. Interestingly, in Wittgenstein's Lecture on Ethics he says 'I wonder at the existence of the world..$^{13}$ But wonder here is not wonder at mystery, even if such wonder leads a person to acknowledge a divine nature that is a mystery.

The point of all this is not that the terms 'mystery' and 'the mysterious' are the private property of the theologians, as that we need to see what the new application is doing, especially in connection with the idea of 'reality as it "anyway" is, independently of human perspective'. What would it mean to be attuned to or to act in consonance with what is thus mysterious - or fail to be? My difficulty with and hesitation about an idea of the 'mysterious' cut free from theology concerns precisely how to make sense of it as something we could be attuned to or consonant with. And the question is whether it genuinely cuts free, or smuggles back some kind of theistic content. In any event, 'the mysterious' seems to be already thereby loaded with a content that cannot really be provided simply by the phrase 'reality as it anyway is'. It is not just what is hidden or concealed from us that warrants talk of 'mystery', but the creative source and sustainer of all things, i.e., it is something worshipped. To put it another way, what is not worshipped is not that mysterious!

Certainly Cooper wants to keep clear of any theistic content. He reports a conversation with his Theology colleague, Andrew Louth, about why even an apophatic theology cannot provide what he wants from his account of mystery. He refers to two opposite tendencies of theologians, to make God too human and to make him too transcendent to provide the measure he is looking for. As for being 'too human' he claims that God is 'too much a denizen of the human world ... to provide measure for our conception of the world, too much a "projection", as it were, of what we anyway hold dear and important to serve as any kind of warrant for our holding them so.' ${ }^{14}$ The key idea here is that of 'warrant for our

\footnotetext{
${ }^{12}$ See also Tractatus 6.522: 'There are, indeed, things that cannot be put into words. They make themselves manifest. They are what is mystical.'

${ }^{13}$ L. Wittgenstein, 'A Lecture on Ethics', The Philosophical Review, 74/1 (1965), 3-12 (p. 8).

${ }^{14}$ David E. Cooper, 'Mystery, World and Religion', pp. 59-60.
} 
holding them so' and I shall return to it when I address the alleged hubris of humanism, partly because I wonder whether talk of 'warrant' here suggests a crypto-theism, though we need to see what Cooper thinks he is guarding against and whether what is at fault is a conception of humanism that makes it appear hubristic. If, however, we hold on to a declaration of God's ineffability and utter transcendence we find ourselves with the problem of 'a disjunctive, two levels account of world and mystery.' ${ }^{15}$

Cooper writes trenchantly against the idea of a disjunctive two level account of the notion of 'reality as it "anyway" is, independently of human perspective', and draws on texts from Nietzsche and Heidegger, as well as on the Taoist and Zen traditions as he formulates an account which concludes as follows:

This world is not simply a human world, unthinkable in isolation from us, but at the same time a realisation of, a coming forth of, something to which we can strive to answer and measure up. ${ }^{16}$

'Reality' is not distorted or refracted by human perspective, the thought is rather that we have a necessarily limited purchase on reality, that is to say, a limited purchase on what we do have a purchase on, and an acknowledgment that there is much that we could never grasp. Once we make that latter point, however, we open up a series of fantasy populations to colonise these spaces and, as Cooper reminds us, make various Platonic or Kantian claims about the causal relation between reality as it is in itself and what is available to us in experience.

But I suggested earlier that the bird singing and the frog plopping mentioned by Cooper could be seen as images of things emerging as it were into our ken, being realised, made real to us. But I cannot see how the world thus conceived is a 'coming forth of ... something to which we can strive to answer and measure up', unless we conceive what comes forth precisely as an ethical perspective on the world we already inhabit but which interrogates the terms of that habitation - a perspective discovered, recalled or restored and a human world 'renewed' by that perspective. The Zen monk doesn't simply hear the bird sing or the bamboo rustling, but is aware of it with a tender care for its beauty.

\footnotetext{
${ }^{15}$ Ibid., p. 61. Theologians would have much to say about these claims, but this is not the occasion for discussing them.

${ }^{16}$ Ibid., p. 58.
} 


\section{APPEARANCE AND REALITY}

As a means of reflecting on the way Cooper talks about 'reality as it "anyway" is, independently of human perspective, it might be helpful here to turn to an informal sketch of the ambiguities within the distinction between appearance and reality, and how the various ways in which things appear to us can conceal or reveal their nature - and ours.

There are straightforward empirical applications of this distinction, where to talk about 'reality' is to talk about how particular things are as opposed to how they seem or appear to be. What we have here is a corrective distinction. Whereas things can be just as they appear to be, appearances can also be deceptive and we need to be able to correct them. To talk about reality in this kind of context is to talk about the truth of the matter, the 'reality of the situation'.

There are related uses, as when we say that ideological mystification masks the real nature of the relations of production, for instance, where the general appearance of things constitutes an illusion from which people need to be freed, and the functional point of the claim is that under appropriate conditions access is available to the truth of the matter. This might be through closer empirical investigation as in the case of an intermittently false consciousness or, and it starts now to look more tenuous, by metaphysical argument to a rationalist monism, for instance, or, even more dubiously, by mystic insight into the real nature of things. Such disturbing claims are empty unless they can be backed up and the truth revealed by some corrective procedure, so that a general appearance is discovered to be some kind of distortion or blindness. This is not an anti-verificationism issue - such claims can be made without our having any means of establishing their truth or falsity - the point rather, is that people make discoveries that lead them to realise and then declare that the reality is different from the appearance. There can be intimations of this kind of possibility as powerful as the Tintern Abbey moment, but it is often the painful matter of discovering or seeing the world at last without previous illusion, as in the case of Eliot's talk of things ill done ... which once we took for exercise of virtue.

There is however a less absolute distinction between appearance and reality in which we want to insist upon how things manifest themselves to sense or other forms of empirical observation, where such appearance is not opposed to 'reality' but is a form of its expression. Nevertheless the implication is that we have a necessarily limited experience of reality 
which impresses itself upon us just to the extent and in the ways that we can be thus 'impressed' upon - and that much must elude us because the possibilities for that manifestation depend upon our limited faculties and instruments, so that whatever lies outside their range and how it operates is beyond the scope of our understanding. In this sense, all we have is 'appearance' and it would be an error to seek to apply the corrective distinction to this. This distinction between appearance and reality is not an absolute one since appearance here is precisely of reality - or such reality as we are able to assimilate or accommodate into the human world, which is a space or home we have carved out for ourselves within reality, although this home is not entirely wind and water tight, and it can be limited in its dimensions by moral obtuseness or attachment. What appears to us is not to be 'corrected' by reality, but it may betray a limitation of scope that keeps particular realities at bay.

Professor Cooper's talk of 'reality as it "anyway" is, independently of human perspective' might be taken to imply that there is a truth of the matter - what we have a perspective on - by reference to which we estimate the adequacy of a perspective in the light of another, as when we are wiping the breakfast table. Our perspective on the table from over here fails to reveal the coffee stain that is in plain view when we change our position. That there is a coffee stain is the reality, the truth of the matter, that is available to one perspective but not another, and might not be available to either. But the truth of the matter stands independently of any perspective we might have on it. The perspective that fails to disclose the presence of the stain is not a 'false' perspective, but gives rise to a false impression if we base upon it the judgment that the table is now clean. It is not false but it is inadequate because it fails to pick up a truth we are interested in. The significant thing here, though, is that we can become attached or locked in to perspectives which conceal what we might need to know about, or which prevent a realisation of, realities we have no reason to call 'mysterious'.

In another sense, 'independently of human perspective' seems to refer to whatever might lie as it were permanently beyond the scope of any human perspective or, by contrast, to what is currently outside that scope but which could fall within it under more propitious circumstances. The former of these is a more likely candidate for talk of 'mystery' but implies a transcendence that makes it an unlikely source of 'measure' (by Cooper's own test). The latter seems the more likely candidate for talk 
of realisation or coming forth, but is surely not mysterious since what comes forth is precisely a measure not previously available.

\section{FREUD AND RILKE: FOREIGN TERRITORY AND DAS OFFENE}

I should like to make a connection between this notion of the world as a coming forth with an intriguing remark of Freud's, and to connect both with some thoughts of Rilke about what he calls das Offene.

In the first paragraph of Freud's chapter on the 'Dissection of the Psychical Personality' in the New Introductory Lectures in Psychoanalysis ${ }^{17}$ he deploys a metaphor that repays attention: 'the repressed', he tells us, 'is foreign territory to the ego - internal foreign territory - just as reality (if you will forgive the unusual expression) is external foreign territory.'18

It is an unusual expression, but highly suggestive in the context of what Cooper is drawing attention to, since it suggests a certain idea of resistance to 'reality' which is conceived as 'foreign' in relation to what by contrast must be thought of as 'home', but 'home', I suggest - and this tracks Cooper's own distinction - in the sense of the human world, so that just as what lies over against the Ego is the internal foreign territory of the repressed so what lies over against the World is the foreign territory of 'reality'. If we think in terms of the distinction between Ego and the repressed, the corresponding distinction might be between 'the world' conceived as 'home' or, to keep the edge of defensiveness, 'homeland', with external foreign territory being 'reality' - or better, as I would want to say, such reality as is not (yet) assimilated to the confines of 'the world'. The idea of resistance here implies, as Sartre noticed, that at some subliminal level, or evanescently, we are perfectly well aware of what transcends our dominant perceptions, of what transcends or passes beyond 'the world' we do not want to let go of because we are too much at home in it, too comfortable.

In the eighth of his Duino Elegies Rilke talks about what he calls Das Offene:

${ }^{17}$ Sigmund Freud, 'The Dissection of the Psychical Personality', in The Standard Edition of the Complete Psychological Works of Sigmund Freud, ed. James Strachley (London: Hogarth Press, 1957). I have discussed this passage briefly elsewhere in 'In the Beginning was the Deed: Philosophers, Reality and the World', in Practical Philosophy, Volume 8, No. 2 (2007), 49-53.

${ }_{18}^{18}$... das Verdrängste ist aber für das Ich Ausland, inneres Ausland, so wie die Realität - gestatten Sie den ungwohnten Ausdruck - äusseres Ausland ist.' Ibid., p. 88. 
With all their eyes the animals all see

What lies open. Only our eyes are turned

As it were away and set like snares

Around their clear way out ${ }^{19}$

There is a grotesque or at least ungainly fusion of ideas and images here which passes from what is represented by the direction of our gaze away from das Offene to a representation of our eyes as snares set around it to prevent others from leaving. The direction of our gaze implies that we are in some way hostile to das Offene and to those who are aware of its presence - in a way that recalls the reception of Plato's liberated prisoner. If Freud defines a resident temptation, a resistance, Rilke offers us a description of what it might be to overcome that temptation, though he strongly acknowledges the presence of resistance too. Freud captures the resistance to what will disturb the settled formation of a world, on analogy with the disturbance of the Ego and its formation ... so we can see how this might fit with Cooper's talk of realisation or coming forth: it is not always welcome and this suggests the need for cultivating a certain disposition of openness towards the not yet apprehended or accommodated which, if I understand Rilke, is das Offene just because it is not yet closed off and brought into our purview, confined within the range of our formation. It will always elude this as what still remains there, open to view because it is there to be seen, but unobserved because we live within what we have grasped and, to make full use of the negative associations of 'grasping, our attachments prevent us seeing what is there, which is a vision of things from another perspective which incorporates the values that provide the measure for our lives that Cooper seeks in 'the mysterious'.

When he uses the term 'the world' Cooper generally distinguishes it from the term 'reality'. He occasionally uses them interchangeably, though in the wider sense of the latter. The narrower sense of the former is determined by the interests and perspectives that make it an essentially human world, which is 'the way it is' only in relation to those human perspectives. Such a world is distinguished from 'reality as it "anyway" is, independently of human perspective. It looks as though we have here a larger and a smaller whole or totality, the distinction between them

\footnotetext{
${ }^{19}$ My translation, though I generally refer to the Leishman/Spender translation. Rainer Maria Rilke, Duino Elegies: The German Text with an English Translation, Introduction and Commentary by J. B. Leishman \& Stephen Spender (London: The Hogarth Press, 1948), pp. 76-81.
} 
mediated by the presence or absence of human concerns - and it is the presence of this human perspective that determines a world and the implication is that the concept of 'reality' transcends that of 'the world' a world in this sense is just such reality as we apprehend, reality as seen and acted in from the point of view of such perspectives, interests, etc. In other words, there is no absolute distinction here - the world is always a human world and just is such reality as we scramble around and have as it were a purchase on - a habitation - and what we have a purchase on will always be determined by, restricted to, our finite powers of apprehension, but also the nature of our interests and our attachments or 'graspings'.

\section{IS HUMANISM REALLY HUBRISTIC?}

Remember that the idea of 'mystery' or 'the 'mysterious' had a strategic role in the overcoming of what Cooper considers to be a philosophical impasse that arises when you want to deny both a certain kind of absolutism and what he came to see as an 'impossibly raw and hubristic style of humanism'. What he has in mind is 'the claim, or boast, that human commitments, values and perspectives neither permit nor require any warrant beyond themselves - for there is no "beyond" for them to answer to. In Sartre's words, there is "no legislator" but man, so that "life is a game" whose "principles man himself ordains"'. Cooper observes that this 'raw humanism' is hubristic since 'it attributes to human beings a capacity they do not have - that of genuinely living with the thought that nothing they commit themselves to, none of the values and beliefs they embrace, can be answerable to anything beyond this commitment and embrace. ${ }^{20} \mathrm{He}$ thinks that anyone who claims such a capacity 'cannot really believe what they are saying':

For when immersed in the stream of life, we are required to make decisions, take directions and pursue objectives that it is impossible for us to regard as having no further authority than their being the ones we happen to have made, taken and pursued. If that were the only authority, then it could not have mattered to us if the decisions, directions and objectives had been different. And that is tantamount to saying that nothing we do matters more or less than anything else. ${ }^{21}$

\footnotetext{
${ }^{20}$ David E. Cooper, 'Mystery, World and Religion', p. 53.

${ }^{21}$ Ibid.
} 
I want to see just what we should resist in the raw, hubristic humanism Cooper sketches out here since the way we look at it will make a difference to how we conceive the alternatives. What is the conception that Cooper thinks cannot be lived? '[W] hen immersed in the stream of life, we are required to make decisions, take directions and pursue objectives that it is impossible for us to regard as having no further authority than their being the ones we happen to have made, taken and pursued. If they have no further authority than that, then it could not have mattered to us if they had been different.

So, what is the point of introducing a question of 'authority' here in relation to decisions, directions and objectives? The first thing to observe is that what Cooper talks about are things that we do - make decisions, take directions and pursue objectives. It at least makes sense, in that case, to talk about our having reasons for doing the one thing or the other, so that whether it matters whether we do the one thing or the other is a question we can only answer in the light of a consideration of those reasons and the relationship in which we stand to them. We are, generally, 'answerable' for our actions; when we think of a measure for judging how we live we are again concerned with our conduct.

But if we look at what else Cooper says in indicting the hubris of this humanism, what we find is that his approach is problematically voluntaristic. He talks about the claim, or boast, that human commitments, values and perspectives (my italics) neither permit nor require any warrant beyond themselves - for there is no 'beyond' for them to answer to. In Sartre's words, there is 'no legislator' but man, so that 'life is a game' whose 'principles man himself ordains'. What we need, according to Cooper, is a 'beyond the human', 'something which could serve to give measure to our lives'. Essentially Cooper is claiming that we cannot allow that our commitments, etc., have no warrant beyond themselves but he concludes, wrongly in my view, that what we need is a 'beyond the human' which could serve to give measure to our lives.

The problem is that Cooper offers us a mixed list - 'commitments, values and perspectives' - and only one of these - commitments - lends itself to Sartre's talk of 'legislation' or what we 'ordain'. It is only in the case of commitment that we can readily talk of something that we do and it is only in the case of what we do that we can really talk about 'answerability'. If I am answerable to someone I have to defend or justify my conduct to them. In a similar way, if we talk about 'answerability' or 'measurement', then it is our actions, our conduct, that we measure or 
answer for. It looks as though when Cooper talks of 'a beyond the human' he is really thinking, quite properly, of something beyond the human will or, better, beyond the mere fact that we will things so. The metaphor of setting a value on something can lead us into thinking that we confer value and once we start thinking in that way we are likely to go on to the thought that this conferring of value is a bare act of the will and that we can as easily withdraw as confer, whereas it is in the light of reasons that our will points in one direction rather than another; and we do not choose these reasons.

However, by contrast, if we come to the question of the values and perspectives that we 'embrace' (a term which misleadingly suggests a voluntary act) it should be clear that we are not naming things that we do but rather the point of view or perspective in the light of which we do them or fail to do them, so that our answerability - the context in which we tend to think in terms of being answerable - is partly a function of how we regard our failure to act. We are talking of the terms in which we assess whether we have acted well or badly and these are not the product of the will. It is true that they are not warranted, but that is because they are the warrant for our actions, the terms in which we judge them. Our values and perspectives are not the products of the human will: they inform it, provide the measure by which we judge our actions - they are if you like the 'conscience' to which we are answerable and it has 'authority' because it is by reference to it that we make our judgments. We do not choose our values, nor do we choose the perspective in the light of which we regard the world. We do not choose that it is the case that these considerations move us ... This provides the terms in which we judge whether our doing this or some other thing matters. Sartre's voluntarism is askew, but askew for an interesting reason. He makes human beings the legislators because his version of atheism depends upon a theology of the divine will as determining the rightness or wrongness of action and, in the absence of that divine being, the only other will that is available is the human one. But theologically the divine will is already the will of a just and loving God, so if our atheism takes account of that we are not so much left with the human will as a will that is informed at least some times by considerations of love and justice, in whose absence the race languishes. It is not how the will happens to be disposed that matters but what informs that disposition.

What I have resisted is the idea that 'mystery' has a significant role to play in the emergence of what Cooper calls 'measure for our lives'. What 
I should want to endorse, however, is the idea of a realisation or coming forth of what we might be said to answer to. The image he provides of the Zen monk and an attentive silence is the image of the calming of the passions which allows a dormant or overlain moral perspective to emerge into view, a coming forth whose possibility we otherwise resist because it disturbs the settled domesticity of a human, all too human world. This form of attention is indeed an attention to reality in the sense that it puts into question the contours and limits of the world we find ourselves not very securely at home in. 